\title{
EXPERIMENTAL INSIGHTS OF USING WASTE MARBLE FINES TO MODIFY THE GEOTECHNICAL PROPERTIES OF A LATERITIC SOIL
}

\author{
Isaac I. AKINWUMI', Colin A. BOOTH ${ }^{\mathrm{b}}$ \\ ${ }^{a}$ Department of Civil Engineering, College of Engineering, Covenant University, Ota, Nigeria \\ ${ }^{b}$ Construction and Property Research Centre, Faculty of Environment and Technology, \\ University of the West of England, BS16 1QY Bristol, UK
}

Submitted 25 Aug. 2014; accepted 24 Dec. 2014

\begin{abstract}
Marble spoil waste is an environmental nuisance. The effects of adding waste marble fines (WMF) on the plasticity, strength and permeability of a lateritic clay have been investigated for its potential use as a soil modifier or stabilizer of road pavement layer materials or earth-building materials. The chemical compositions of the WMF and soil were determined using X-ray fluorescence and atomic absorption spectrometry, respectively. The specific gravity, Atterberg limits, compaction, strength and permeability characteristics of the soil were determined for varying proportions of the soil-WMF blends. The properties of the natural soil - classified as clay of low plasticity (CL) and A-7-6(7), according to unified soil classification and AASHTO classification systems, respectively - were improved after the addition of $10 \%$ WMF such that it behaves like a silt of low plasticity. Therefore, WMF is recommended as a low-cost soil modifier or stabilizer for lateritic soil and well-suited for road construction applications.
\end{abstract}

Keywords: marble dust, waste reuse, soil modification, soil plasticity, soil strength, soil permeability, soil stabilization.

\section{Introduction}

Marble is a versatile material, principally used for construction, interior decoration and in sculptures. Its use in construction of monumental buildings, such as the Taj Mahal in India, attests to its durability, ease of maintenance, lustrous colour, glossy appearance and its ability to take a very high polish (Liguori et al. 2008; El-Gammal et al. 2011).

While extracting or quarrying, cutting and polishing to obtain finished marble products, a significant amount of marble waste is usually generated. During the quarrying process, the extracted stones are cut into large bloc$\mathrm{ks}$, which are typically $3 \mathrm{~m}$ long, $1.5 \mathrm{~m}$ wide and $1.5 \mathrm{~m}$ deep. The blocks are then transported to processing plants and cut into slabs $(2-3 \mathrm{~cm}$ thick) and tiles. The quarrying, cutting and polishing to obtain finished marble products generate about $40 \%$ of the volume of the extracted marble blocks as waste (Saboya Jr. et al. 2007). The cutting process alone generates marble dust of about $20-30 \%$ of the weight of the marble blocks (Agarwal, Gulati 2006; Alyamac, Ince 2009).

Marble waste is a source of concern to marble manufacturers and environmentalists (Segadaes et al. 2005;
Acchar et al. 2006a, 2006b). The finest wastes are readily transported by wind, which can cause air and visual pollution in marble quarries and processing plants. Those wastes dumped on land usually alter the landscape, where the wastes are placed as overburden, and can greatly reduce surface water percolation into the ground. Moreover, they can increase the alkalinity of a soil and reduce its fertility, making the soil unsuitable for cultivation (Montero et al. 2009).

Given the nuisance of the spoil, attempts have been made to incorporate marble waste into many construction materials, which include modifying cement mortar properties (Hwang et al. 2008; Corinaldesi et al. 2010), application as a recycled aggregate in concrete production (Binici et al. 2008; Gencel et al. 2012; Topcu et al. 2009; Ergun 2011; Hebhoub et al. 2011; Belaidi et al. 2012; Bacarji et al. 2013; Andre et al. 2014), as an aggregate in asphaltic concrete (Akbulut, Cahit 2007; Karasahin, Terzi 2007), as a raw material in brick production (Bilgin et al. 2012; Eliche-Quesada et al. 2012) and as raw material in cement production (Aruntas et al. 2010; Aliabdo et al. 2014).

Few works have investigated the effective use of marble wastes for geotechnical engineering purposes such as

Corresponding author: Isaac I. Akinwumi

E-mail: isaac.akinwumi@covenantuniversity.edu.ng 
for improving the workability, modifying the drainage characteristics, strengthening and improving the deformation characteristics of soils. Marble wastes also have the potential of being used to remediate contaminated soils. The workability of a soil is improved by reducing its plasticity, therefore, allowing construction engineers to easily manipulate the physical properties of the soil. The drainage characteristics of a soil can be obtained from tests that determine the hydraulic conductivity or permeability of the soil. For soils used as the core of earth-fill dams and base (pavement) layer materials, it is necessary that they exhibit low permeability. California bearing ratio (CBR) and unconfined compressive strength (UCS) of a soil are measures of its strength and deformation characteristics. The higher the CBR and UCS of a soil the greater its capacity to bear structural load and the lesser its deformation. Okagbue, Onyeobi (1999) and Baser (2009) evaluated the possibility of using marble dust to stabilize a red tropical soil and an expansive soil, respectively. While Okagbue, Onyeobi (1999) focused on assessing the plasticity, compressive strength and California bearing ratio (CBR) of red tropical soil and its mixture with varying proportions of marble dust, Baser (2009) focused on evaluating the plasticity and swell potential of the expansive soil and its mixture with varying percentages of marble dust.

The purpose of this study is to investigate the effects of adding waste marble fines (WMF) on the plasticity, strength and permeability of the most widely available soil type (lateritic soil) in tropical and sub-tropical countries. The geotechnical properties of some of the lateritic soils found in these countries do not satisfy standard requirements for use as road construction materials. Portland cement and lime are well-known and effective stabilizers or modifiers for the improvement of the geotechnical properties of lateritic soils, but these stabilizing agents are expensive. In recent years, research works on the use of low-cost alternative materials and particularly waste materials in the construction industry are becoming attractive and have been encouraged (Marzouk et al. 2013; Malaiskiene et al. 2014; Marciukaitis, Jurkenas 2013). The use of WMF to improve the geotechnical properties of lateritic soils seem, therefore, appealing because of their low cost and potential to rid the environment of the nuisance and human health impact associated with their indiscriminate disposal.

\section{Methodology}

\subsection{Materials}

The WMF used in this experimental study were sourced from a marble manufacturing company in Lagos, Southwestern Nigeria. The particles of the WMF easily passed through a $0.425 \mathrm{~mm}$ sieve, while $87 \%$ of it passed through a $0.075 \mathrm{~mm}$ sieve. This is similar to the gradation of marble dust used by Karasahin, Terzi (2007).
A clay soil obtained from a borrow pit at Agbara, Ogun State, Southwestern Nigeria, with a deep lateritic soil profile, was used in this study. The soil was collected from the sidewall of the soil profile at a depth of about 10 $\mathrm{m}$ from the top of the pit. This soil profile had been exposed by borrowing activities of several months. Some of the soil samples were collected and stored in a water-tight container for laboratory determination of their natural moisture contents before they were transported to the soil laboratory. Prior to conducting tests on the soil samples for other laboratory determinations, they were air-dried, passed through a $4.75 \mathrm{~mm}$ sieve (AASHTO T 99-10 2010) and thoroughly mixed.

\subsection{Experimental Work}

Geochemical characterization of the soil and WMF were determined using atomic absorption spectrophotometer (Pelkin Elmer 3300) and X-ray fluorescence (Philips PW 1400), respectively. Representative samples of the air-dried soil were obtained by the process of quartering into parts of equal mass. WMF were added to each of the four parts in $0 \%, 2 \%, 6 \%$ and $10 \%$ proportions by dry weight of the soil sample, respectively.

Gradation tests were carried out on the soil sample. Specific gravity, Atterberg limits, compaction, unsoaked and soaked CBR, unconfined compression and permeability tests were conducted on the natural (0\% WMF content) and treated (2\%, 6\% and 10\% WMF contents) soil samples, respectively. Each of these tests was carried out in triplicate (Akinwumi 2014c) and their mean values determined. The tests were conducted according to the procedures outlined in BSI (1990a; 1990b).

Sieve analysis was carried out on samples of soil retained on a sieve with $0.075 \mathrm{~mm}$ opening while hydrometer analysis, using sodium hexametaphosphate, was conducted on the soil sample passing the sieve. Specific gravity of the soil and WMF were determined using a pycnometer. Liquid and plastic limits were determined using the Casagrande apparatus and glass plate.

The British Standard heavy compaction energy was used for preparing the specimens for compaction and CBR tests. Unsoaked CBR test specimens were cured for 7 days under controlled temperature $\left(25 \pm 2{ }^{\circ} \mathrm{C}\right)$ and relative humidity (100\%). For the determination of soaked CBR, specimens were cured for 6 days under the controlled temperature and the relative humidity before being immersed in water for 24 hours. Unconfined compressive strength (UCS) test specimens $(50 \mathrm{~mm} \times 100 \mathrm{~mm})$, prepared and extruded from a cylindrical mould, were cured in sealed plastic bags. The UCS for each test batch was determined after 28 days of curing. Falling head permeameter was used to determine the coefficient of permeability of the samples. 
Gradation tests, comprising of sieve analysis and hydrometer analysis, were carried out on the soil sample to determine the particle size distribution of the soil. Soil moisture content determinations were carried out using the oven drying method. Determinations of the specific gravity of the soil samples were necessary because it gives a measure of the density of the soil solids and can also be helpful in calculating their phase relationships. Liquid and plastic limits tests were the Atterberg limits tests conducted. They were performed to characterize the state or condition of the soil sample based on its water content. The CBR values of the natural and treated soil samples were used to evaluate their potential strength, when used as road pavement layer materials. Unconfined compression test on the natural and treated soil samples were carried out to determine their unconsolidated undrained strength. Falling head permeability test was conducted on the natural and treated soil samples to determine their coefficients of permeability.

\section{Results}

\subsection{Chemical Composition of Soil and WMF}

The chemical constituents of the WMF and soil sample are presented in Figure 1. The WMF consists predominantly of lime $(\mathrm{CaO})$ while the soil sample is rich in silica $\left(\mathrm{SiO}_{2}\right)$. The ratio of silica-sesquioxides for the soil was determined to be 1.66 , indicating that the soil is lateritic. A ternary of the composition of silica and sesquioxides of the soil sample with Schellmann (1986) scheme of classification of weathering products is shown in Figure 2.

The plot for this soil sample fell within the area of the chart classified as kaolinization, indicating that the soil sample was taken from a kaolinized profile.

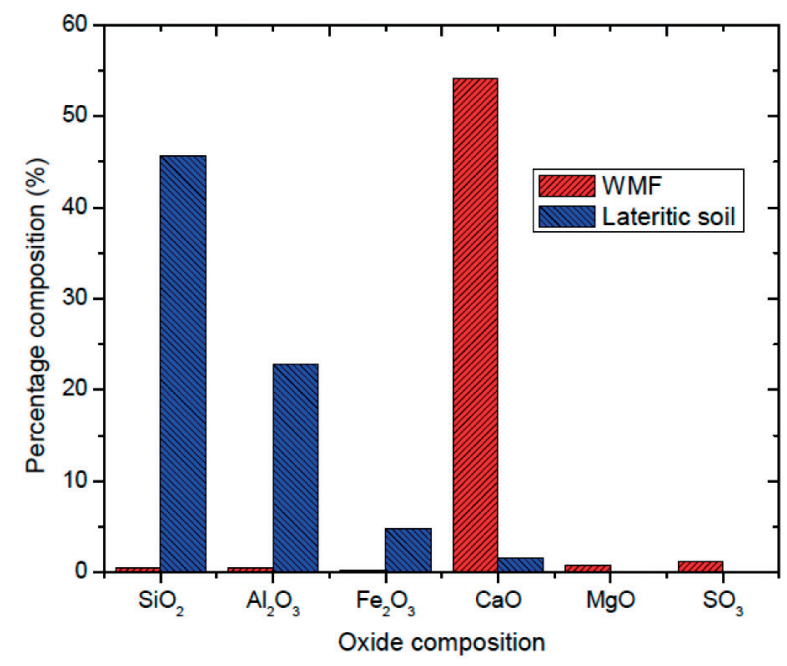

Fig. 1. Chemical compositions of the WMF and soil sample

\subsection{Natural soil}

The physical and mechanical properties of the natural soil are summarily presented in Table 1 . The soil sample, classified as A-7-6 (7) in accordance with American Association of State Highway and Transportation Officials

Table 1 . Physical and mechanical soil property characteristics

\begin{tabular}{|c|c|c|}
\hline & Properties & $\begin{array}{l}\text { Mean Value / } \\
\text { Description }\end{array}$ \\
\hline \multirow{5}{*}{$\begin{array}{l}\text { Gra- } \\
\text { dation / } \\
\text { Classi- } \\
\text { fication }\end{array}$} & Gravel (>4.75 mm), \% & $0.5( \pm 0.05)$ \\
\hline & Sand $(0.075-4.75 \mathrm{~mm}), \%$ & $44.0( \pm 1.70)$ \\
\hline & Silt and Clay $(<0.075 \mathrm{~mm}), \%$ & $55.5( \pm 1.20)$ \\
\hline & $\begin{array}{l}\text { AASHTO Soil Classification } \\
\text { System }\end{array}$ & A-7-6 (7) \\
\hline & $\begin{array}{l}\text { Unified Soil Classification } \\
\text { System }\end{array}$ & CL - Sandy clay \\
\hline \multirow{9}{*}{ Physical } & Colour & Brown \\
\hline & Natural Moisture Content (\%) & $15.6( \pm 1.28)$ \\
\hline & Specific Gravity & $2.51( \pm 0.03)$ \\
\hline & Liquid Limit (\%) & $41.0( \pm 2.59)$ \\
\hline & Plastic Limit (\%) & $23.0( \pm 1.06)$ \\
\hline & Plasticity Index (\%) & $18.0( \pm 0.35)$ \\
\hline & $\begin{array}{l}\text { Maximum Dry Unit weight } \\
\left(\mathrm{kN} / \mathrm{m}^{3}\right)\end{array}$ & $18.2( \pm 0.10)$ \\
\hline & $\begin{array}{l}\text { Optimum Moisture Content } \\
(\%)\end{array}$ & $15.3( \pm 0.36)$ \\
\hline & $\begin{array}{l}\text { Coefficient of Permeability } \\
(\mathrm{cm} / \mathrm{s})\end{array}$ & $\begin{array}{c}8.24 \times 10^{-6}( \pm 0.31 \\
\left.\times 10^{-6}\right)\end{array}$ \\
\hline \multirow{3}{*}{ Strength } & Unsoaked CBR (\%) & $18( \pm 1.15)$ \\
\hline & Soaked CBR (\%) & $10( \pm 0.35)$ \\
\hline & $\begin{array}{l}\text { Unconfined Compressive } \\
\text { Strength }\left(\mathrm{kN} / \mathrm{m}^{2}\right)\end{array}$ & $560( \pm 22.3)$ \\
\hline
\end{tabular}

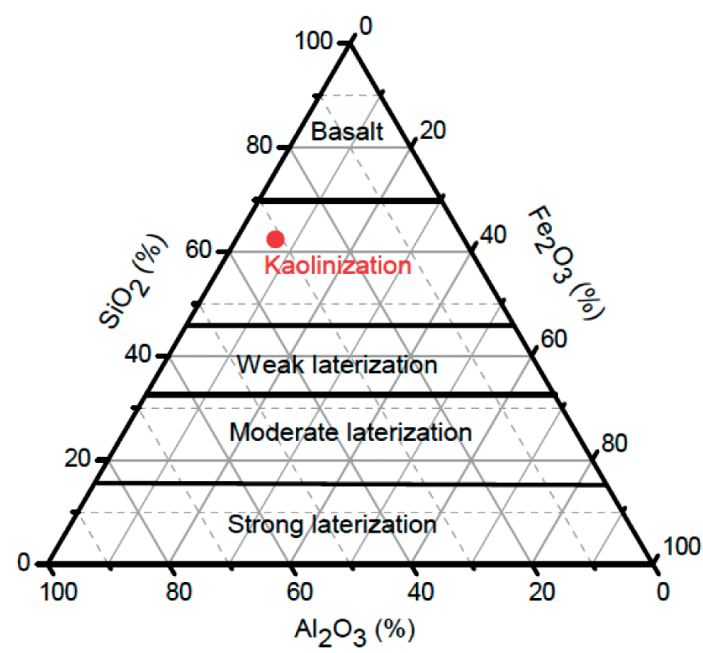

Fig. 2. $\mathrm{Al}_{2} \mathrm{O}_{3}-\mathrm{SiO}_{2}-\mathrm{Fe}_{2} \mathrm{O}_{3}$ ternary plot for the soil sample 


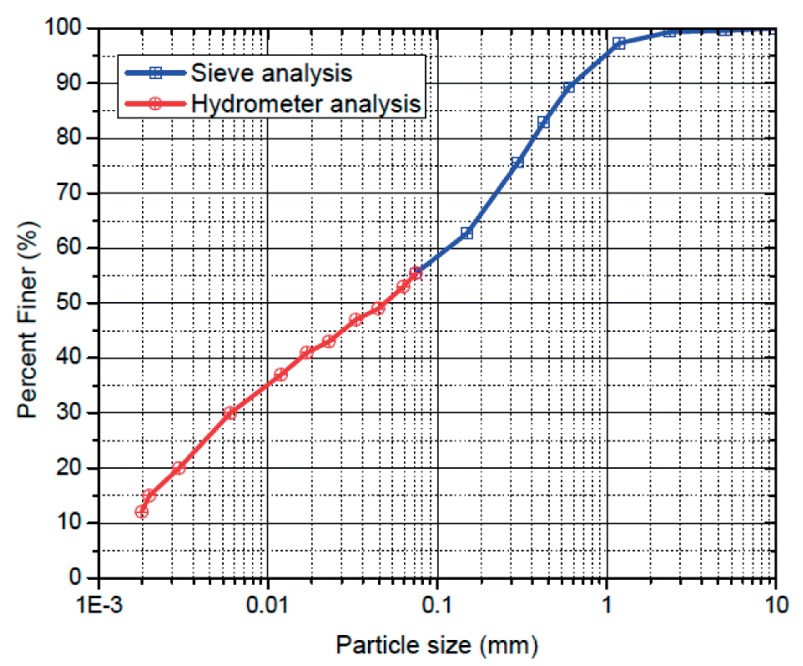

Fig. 3. Particle size distribution of tested soils

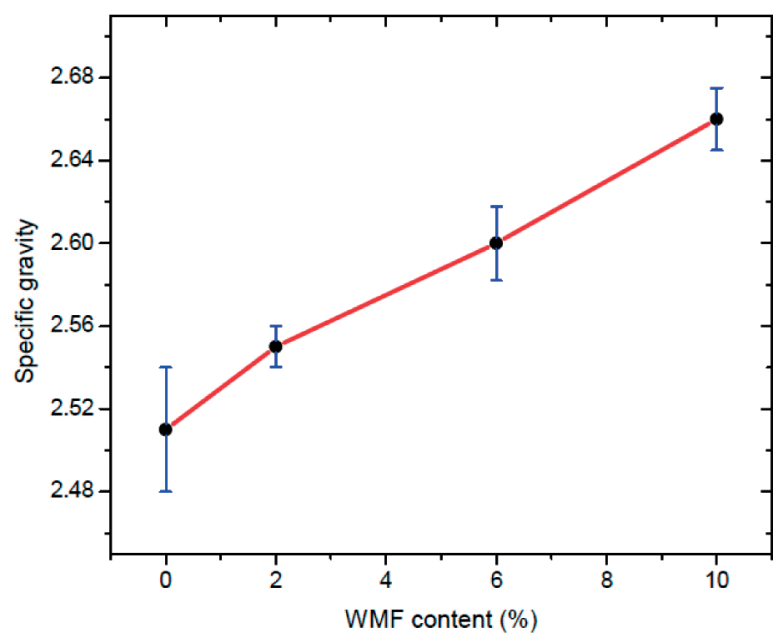

Fig. 4. Variation of specific gravity of the treated soil samples with their WMF contents

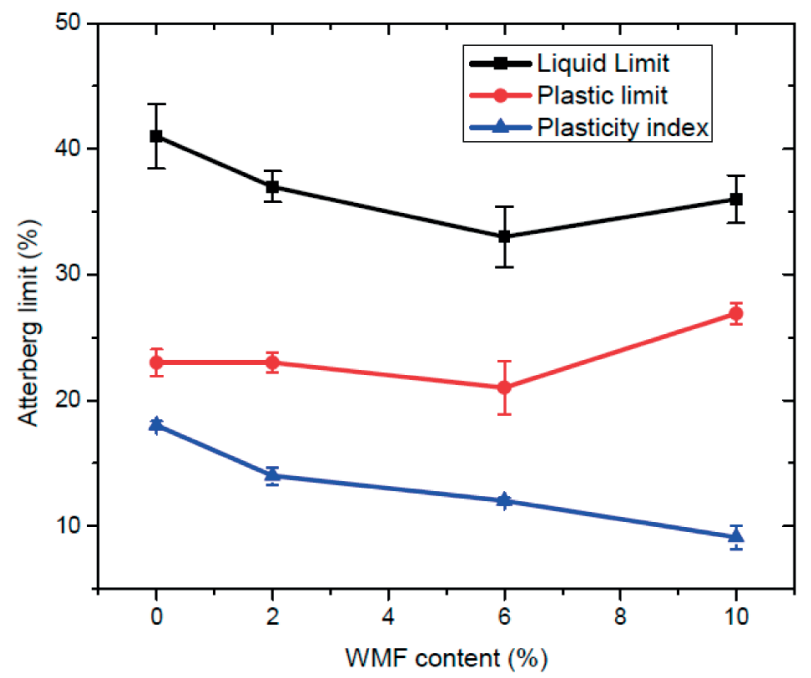

Fig. 5. Variation of Atterberg limits of the treated soil samples with their WMF contents
(AASHTO) system of soil classification and sandy lean clay (CL) in accordance with the Unified soil classification (USC) system, has an average natural moisture content of $15.6 \%$ and a specific gravity of 2.51 . Its unconfined compressive strength, unsoaked and soaked CBR values are generally low. The particle size distribution of the soil is shown in Figure 3. The shape of the particle size distribution curve indicates that the soil is well-graded. About fifty six percent $(55.5 \%)$ of the soil's particle sizes passed the $0.075 \mathrm{~mm}$ sieve, indicating that this portion significantly influenced the plasticity, strength and permeability characteristics of the soil.

\subsection{Effects of Adding WMF to the Soil}

\subsubsection{Specific gravity}

The specific gravity of the WMF is 2.8 . The result of the specific gravity tests on the treated soil samples is graphically presented in Figure 4. The specific gravity of the treated soil samples increased as their WMF content increased. After adding 10\% WMF, the specific gravity of the treated soil (when compared with that of the natural soil) increased by $4.4 \%$. There is a strong correlation $(r=0.997)$ between the specific gravities of the treated soil samples and their WMF contents.

\subsubsection{Atterberg limits}

The result of the Atterberg limits tests on the treated soil samples is graphically presented in Figure 5. There is a slight negative correlation between the liquid limits and plasticity indices of the treated soil samples and their WMF contents. There is, however, no correlation between the plastic limits of the treated soil samples and their WMF contents. This implies that while the water contents at which the natural soil and the treated soil samples changed from being plastic to being semi-solid remains fairly constant, the range of water contents at which the treated soil samples behaved like a plastic decreased with increasing WMF content.

This may be attributed to cation exchange and dissociation. The cation exchange occurred between the lime-rich WMF and the water in the soil and this led to the coating of some of the clay particles of the soil by the clay-size particles of the WMF. This coating minimized the interaction between the water and the clay particles of the soil, thereby resulting in the reduction of the soil's moisture-holding capacity and making it more workable. This is a consequence of the decrease in liquid limits and plasticity indices of the treated soil samples as their WMF contents increased.

$$
\begin{gathered}
\mathrm{CaO}+\mathrm{H}_{2} \mathrm{O} \rightarrow \mathrm{Ca}(\mathrm{OH})_{2} \text { (Cation exchange) } \\
\mathrm{Ca}(\mathrm{OH})_{2} \rightarrow \mathrm{Ca}^{2+}+2 \mathrm{OH}^{-} \text {(Dissociation). }
\end{gathered}
$$


Addition of $10 \%$ WMF to the soil reduced its plasticity index by $49.4 \%$. The decrease in the plasticity indices of the treated soil samples as their WMF contents increased is strongly correlated, $\mathrm{r}=-0.964$.

\subsubsection{Compaction characteristics}

Optimum moisture content (OMC) and maximum dry unit weight of the natural and treated soil samples were obtained from compaction tests. Figure 6 shows a graphical illustration of the maximum dry unit weight and OMC of the natural and treated soil samples. The maximum dry unit weight of the treated soil samples increased as their WMF contents increased. This increase is strongly correlated, $r=0.961$. The increase in maximum dry unit weight of the treated soil samples as their WMF content increased can be attributed to the higher specific gravity or density of the WMF (2.8), when compared with that of the soil (2.51).

The OMC of the treated soil samples decreased as their WMF content increased. This decrease is strongly correlated, $\mathrm{r}=-0.979$.

Figure 7 shows the plasticity charts for AASHTO and USC systems with the plasticity plots for the natural and treated soil samples. It shows that the lateritic clay soil (classified as A-7-6 and CL) became silty (A-4 and ML) after $10 \%$ WMF was mixed with the soil.

The decrease in the OMC can, thus, be attributed to the agglomeration of the clay particles of the soil and claysize particles of the WMF. This makes them behave like silt-size particles (Fig. 7). The coarser a soil becomes the lesser water it requires to reach optimum (Akinwumi et al. 2012; Akinwumi 2014b).

\subsubsection{Strength characteristics}

CBR tests were conducted for both unsoaked and soaked treated soil samples. The variation of unsoaked and soaked CBR values of the treated soil samples with their WMF content is presented in Figure 8. The unsoaked CBR of the treated soil samples increased as their WMF contents increased. After adding 10\% WMF, the unsoaked CBR of the treated soil sample, when compared with that of the natural soil, increased by $205.6 \%$. The increase in the unsoaked CBR values of the treated soil samples, as their WMF contents increased, is strongly correlated $(r=0.854)$. The soaked CBR value of the treated soil samples also increased as their WMF contents increased. Addition of $10 \% \mathrm{WMF}$ increased the soaked CBR value of the treated soil sample by $360 \%$. The increase in the soaked CBR values of the treated soil samples, as their WMF contents increased, is strongly correlated $(\mathrm{r}=0.901)$.

Figure 8 also shows the variation of unconfined compressive strength (UCS) of the treated soil samples

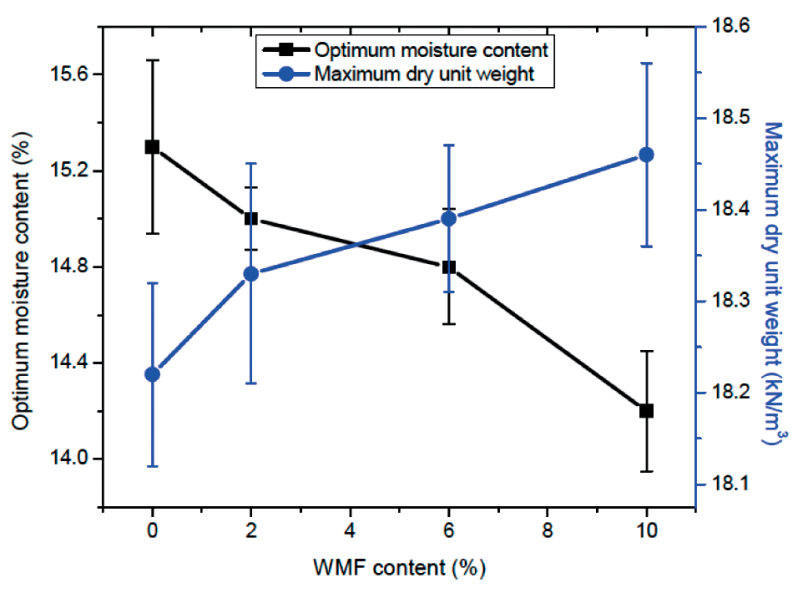

Fig. 6. Variation of compaction characteristics of the treated soil samples with their WMF contents

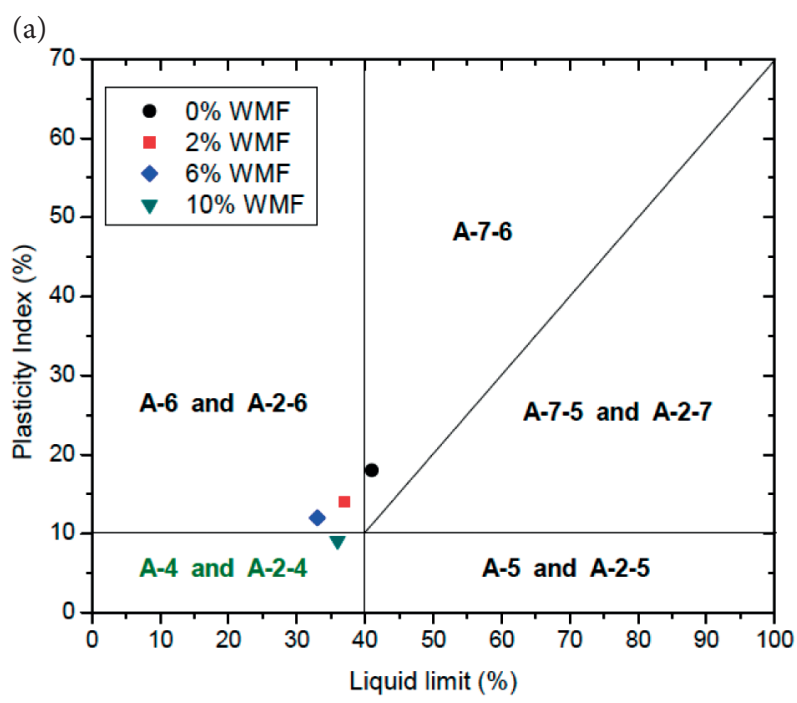

(b)

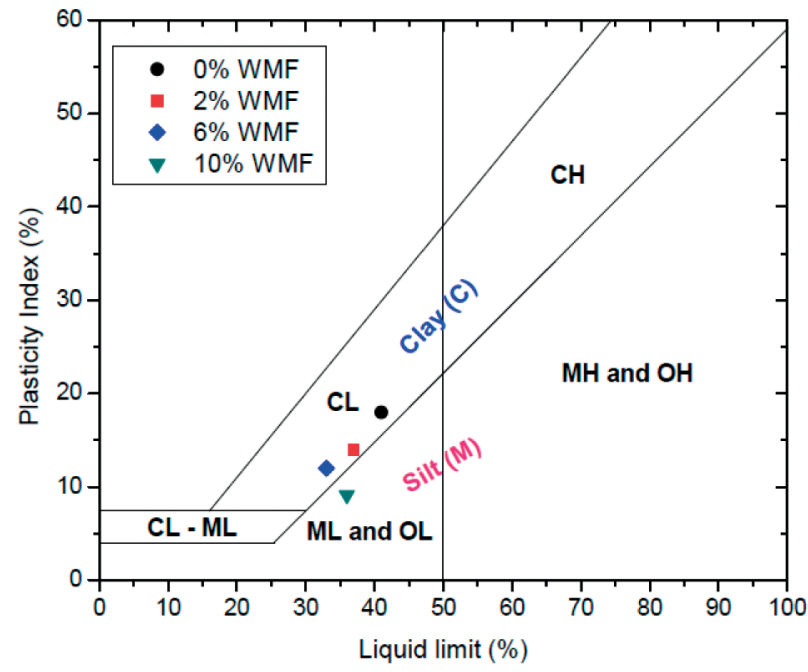

Fig. 7. Plasticity charts (a) AASHTO (b) USC showing the plots for the mean values for the natural and treated soil samples 
with their WMF contents. The UCS of the treated soil samples increased as their WMF contents increased. This increase is strongly correlated, $\mathrm{r}=0.976$. After adding $10 \%$ WMF, the UCS of the treated soil sample increased by $311.3 \%$.

The reactions between the lime-rich WMF and the silica- and alumina-rich soil sample, in the presence of water, forms calcium-silicate-hydrates and calcium-aluminate-hydrates, respectively. These cementitious products are thought to be responsible for the increase in the unsoaked and soaked CBR values and unconfined compressive strength of the treated soil samples, as their WMF contents increased.

$$
\begin{gathered}
\mathrm{Ca}^{2+}+2 \mathrm{OH}^{-}+\mathrm{SiO}_{2} \rightarrow \mathrm{CaO} \cdot \mathrm{SiO}_{2} \cdot \mathrm{H}_{2} \mathrm{O} \\
(\text { Calcium-silicate-hydrate }) \\
\mathrm{Ca}^{2+}+2 \mathrm{OH}^{-}+\mathrm{Al}_{2} \mathrm{O}_{3} \rightarrow \mathrm{CaO} \cdot \mathrm{Al}_{2} \mathrm{O}_{3} \cdot \mathrm{H}_{2} \mathrm{O} . \\
(\text { Calcium-aluminate-hydrate })
\end{gathered}
$$

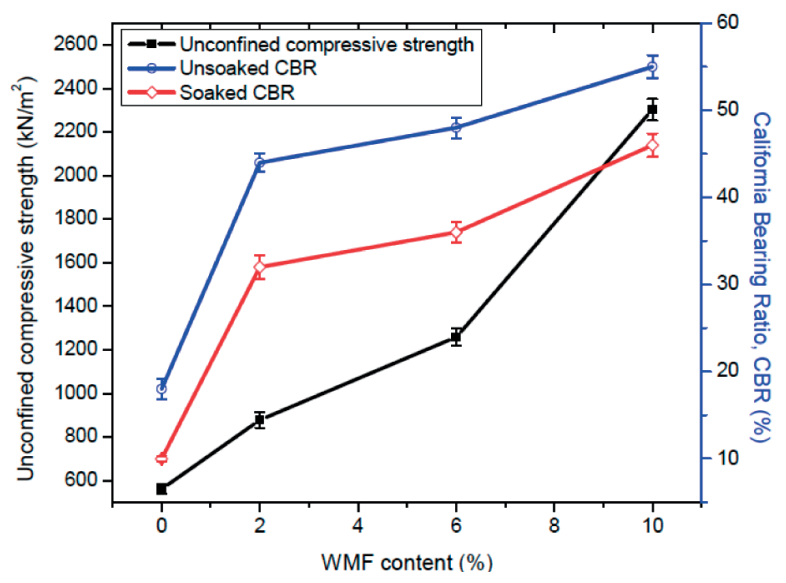

Fig. 8. Variation of strength characteristics of the treated soil samples with their WMF contents

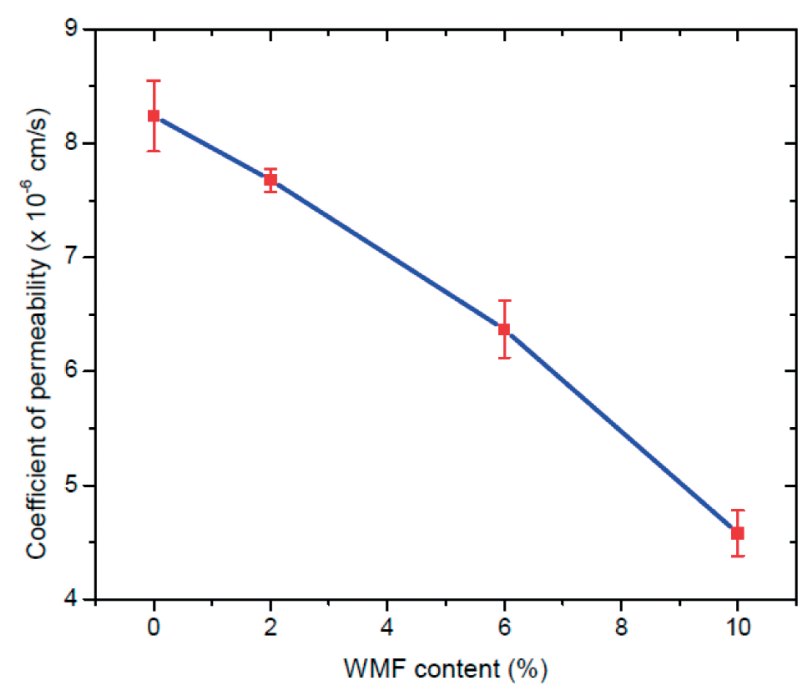

Fig. 9. Variation of permeability characteristics of the treated soil samples with their WMF contents

\subsubsection{Permeability}

The result of permeability tests on the treated soil samples is graphically presented in Figure 9. The coefficient of permeability of the treated soil samples decreased as their WMF contents increased. After adding 10\% WMF, the coefficient of permeability of the treated soil decreased by $44.4 \%$. The decrease in the coefficient of permeability of the treated soil samples, as their WMF contents increased, is strongly correlated $(r=-0.995)$.

The WMF occupied part of the pore space within the soil, thereby reducing the volume of voids within it. This reduction in the void space is responsible for the reduction in the ease with which water flows through the soil.

\section{Discussion}

The increase in specific gravities of the treated lateritic clay samples as their WMF contents increased did not deviate from expectation reasoned by deduction from the knowledge that the specific gravity of the WMF is higher than that of the soil sample. Similar results were obtained for expansive soils by Sivrikaya et al. (2014) and Baser (2009).

The liquid limits and plasticity indices of the treated soil samples decreased with their WMF contents, in alignment with the results of Sivrikaya et al. (2014) and Baser (2009) on expansive soils. Although Sivrikaya et al. (2014) and Baser (2009) reported an increase in the plastic limits of the expansive soil with increasing marble dust, the plastic limits of the treated lateritic clay samples were not significantly affected by increasing their WMF contents.

The maximum dry unit weights and OMCs of the treated soil samples increased and decreased, respectively, with an increase in their WMF contents. Although the soil considered by Sivrikaya et al. (2014) is not lateritic, the effect of adding marble dust to the expansive soil on its compaction characteristics is similar to that obtained for this study.

The unsoaked and soaked CBR values and UCS of the treated lateritic clay samples increased with increasing percentages of WMF. Okagbue, Onyeobi (1999) also reported an increase in the unsoaked CBR of red tropical soils with increasing marble dust content. The effects of treating lateritic clay with WMF on its soaked CBR and UCS have not been reported in literature.

The coefficients of permeability decreased as the percentage of WMF in the treated lateritic clay sample increased. The effect of treating lateritic clay with WMF on its permeability has not been reported in literature.

\section{Conclusions}

Addition of WMF to the soil notably altered its geotechnical properties, causing: (i) a reduction of its plasticity, thereby making the soil more workable; (ii) an improvement in its strength; and (iii) a reduction in the soil permeability. 
These findings are important, especially when the treated soil is used as a road pavement layer material or when it directly receives the structural foundation of buildings, as the amount of water that can pass through it becomes reduced-thereby reducing the possibility of water-induced failures and extending the life of the pavement or building structures founded on such soil layers. Flow of water through earth materials used as pavement layer materials weakens the pavement structure and this accounts for the failure or reduction in the lifespan of many flexible pavements.

Evaluating the properties of the soil, relative to a benchmark standard such as TRL (1993), shows that the natural soil-which barely met the requirements for use as a subgrade material-became improved after the addition of $10 \%$ WMF, such that it satisfies the requirement for use as a sub-base material for road pavement construction.

The potential implications of these findings indicate that the environmental nuisance and human health impact associated with the indiscriminate disposal of WMF can be minimized by using it to improve the plasticity, strength and permeability of an in situ lateritic soil, which is otherwise considered unsuitable in its natural state for use as an earth foundation material to bear the structural foundation of proposed civil engineering infrastructures, such as buildings and roads. Furthermore, it may be useful for improving the engineering properties of traditional earth-building construction materials such as those described by Akinwumi (2014a).

Finally, WMF is recommended as a low-cost additive for improving the geotechnical properties of lateritic clay soils. There is need for further research works, especially, on the performance of constructed roads and buildings using WMF. The possibility of using WMF as total or partial replacement for sand in Portland cement mortar and concrete may also be investigated.

\section{Acknowledgements}

The authors would like to acknowledge the contribution of Mr. Bobby Ekanem towards the samples collection and for conducting some of the laboratory tests. Professor Solomon A. Isiorho assisted in proofreading the earlier draft of this paper. The authors hereby appreciate the managements of Julius Berger Nigeria Plc., Euro 65 laboratory, Lagos and Covenant University, whose laboratory facilities were used for this research work.

\section{References}

AASHTO T 99-10 2010. Standard method of test for moisturedensity relations of soils using a 2.5- $\mathrm{kg}(5.5-\mathrm{lb})$ rammer and a 305-mm (12-in.) drop. American Association of State Highway and Transportation Officials, Washington, DC.
Acchar, W.; Vieira, F. A.; Hotza, D. 2006a. Effect of marble and granite sludge in clay materials, Materials Science and Engineering A 419: 306-309.

http://dx.doi.org/10.1016/j.msea.2006.01.021

Acchar, W.; Vieira, F. A.; Segadaes, A. M. 2006b. Using ornamental stone cutting rejects as raw materials for red clay ceramic products: Properties and microstructure development, Materials Science and Engineering A 435-436: 606-610. http://dx.doi.org/10.1016/j.msea.2006.07.091

Agarwal, S. K.; Gulati, D. 2006. Utilization of industrial wastes and unprocessed micro-fillers for making cost effective mortars, Construction and Building Materials 20: 999-1004. http://dx.doi.org/10.1016/j.conbuildmat.2005.06.009

Akbulut, H.; Cahit, G. 2007. Use of aggregates produced from marble quarry waste in asphalt pavements, Building and Environment 42: 1921-1930. http://dx.doi.org/10.1016/j.buildenv.2006.03.012

Akinwumi, I. I.; Adeyeri, J. B.; Ejohwomu, O. A. 2012. Effects of steel slag addition on the plasticity, strength and permeability of a lateritic soil, in 2nd Internation Conference of Sustainable Design, Engineering and Construction proceedings, 7-9 November 2012, Fort Worth, Texas, United States. ASCE, 457-464. http://dx.doi.org/10.1061/9780784412688.055

Akinwumi, I. I. 2014a. Earth building construction processes in Benin City, Nigeria and engineering classification of earth materials used, Indian Journal of Traditional Knowledge 13(4): 686-690.

Akinwumi, I. I. 2014b. Plasticity, strength and permeability of reclaimed asphalt pavement and lateritic soil blends, International Journal of Scientific and Engineering Research 5(6): 631-636.

Akinwumi, I. 2014c. Soil modification by the application of steel slag, Periodica Polytechnica Civil Engineering 58(4): 371-377. http://dx.doi.org/10.3311/PPci.7239

Aliabdo, A. A.; Elmoaty, A. E. M. A.; Auda, E. M. 2014. Re-use of waste marble dust in the production of cement and concrete, Construction and Building Materials 50: 28-41. http://dx.doi.org/10.1016/j.conbuildmat.2013.09.005

Alyamac, K. E.; Ince, R. 2009. A preliminary concrete mix design for SCC with marble powders, Construction and Building Materials 23: 1201-1210. http://dx.doi.org/10.1016/j.conbuildmat.2008.08.012

Andre, A.; de Brito, J.; Rosa, A.; Pedro, D. 2014. Durability performance of concrete incorporating coarse aggregates from marble industry waste, Journal of Cleaner Production 65: 389-396. http://dx.doi.org/10.1016/j.jclepro.2013.09.037

Aruntas, H. Y.; Guru, M.; Dayi, M.; Tekin, I. 2010. Utilization of waste marble dust as an additive in cement production, Materials and Design 31: 4039-4042. http://dx.doi.org/10.1016/j.matdes.2010.03.036

Bacarji, E.; Filho, R. D. T.; Koenders, E. A. B.; Figueiredo, E. P.; Lopes, J. L. M. P. 2013. Sustainability perspective of marble and granite residues as concrete fillers, Construction and Building Materials 45: 1-10. http://dx.doi.org/10.1016/j.conbuildmat.2013.03.032

Baser, O. 2009. Stabilization of expansive soils using waste marble dust: MSc Dissertation. Middle East Technical University, Ankara.

Belaidi, A. S. E.; Azzouz, L.; Kadri, E.; Kenai, S. 2012. Effect of natural pozzolana and marble powder on the properties of 
self-compacting concrete, Construction and Building Materials 31: 251-257.

http://dx.doi.org/10.1016/j.conbuildmat.2011.12.109

Bilgin, N.; Yeprem, H. A.; Arslan, S.; Bilgin, A.; Gunay, E.; Marsoglu, M. 2012. Use of waste marble powder in brick industry, Construction and Building Materials 29: 449-457. http://dx.doi.org/10.1016/j.conbuildmat.2011.10.011

Binici, H.; Shah, T.; Aksogan, O.; Kaplan, H. 2008. Durability of concrete made with granite and marble as recycle aggregates, Journal of Materials Processing Technology 208: 299-308. http://dx.doi.org/10.1016/j.jmatprotec.2007.12.120

BSI 1990a. Methods of test for soils for civil engineering purposes, British Standards Institution, BS 1377, London.

BSI 1990b. Stabilized materials for civil engineering purposes. General requirements, sampling, sample preparation and tests on materials before stabilization, British Standards Institution, BS 1924-1, London.

Corinaldesi, V.; Moriconi, G.; Naik, T. R. 2010. Characterization of marble powder for its use in mortar and concrete, Construction and Building Materials 24: 113-117. http://dx.doi.org/10.1016/j.conbuildmat.2009.08.013

El-Gammal, M. I.; Ibrahim, M. S.; Badr, E. A.; Asker, S. A.; ElGalad, N. M. 2011. Health risk assessment of marble dust at marble workshops, Nature and Science 9(11): 144-154.

Eliche-Quesada, D.; Corpas-Iglesias, F. A.; Perez-Villarejo, L.; Iglesias-Godino, F. J. 2012. Recycling of sawdust, spent earth from oil filtration, compost and marble residues for brick manufacturing, Construction and Building Materials 34: 275284. http://dx.doi.org/10.1016/j.conbuildmat.2012.02.079

Ergun, A. 2011. Effects of the usage of diatomite and waste marble powder as partial replacement of cement on the mechanical properties of concrete, Construction and Building Materials 25: 806-812. http://dx.doi.org/10.1016/j.conbuildmat.2010.07.002

Gencel, O.; Ozel, C.; Koksal, F.; Erdogmus, E.; Martinez-Barrera, G.; Browstow, W. 2012. Properties of concrete paving blocks made with waste marble, Journal of Cleaner Production 21: 62-70. http://dx.doi.org/10.1016/j.jclepro.2011.08.023

Hebhoub, H.; Aoun, H.; Belachia, M.; Houari, H.; Ghorbel, E. 2011. Use of waste marble aggregates in concrete, Construction and Building Materials 25: 1167-1171. http://dx.doi.org/10.1016/j.conbuildmat.2010.09.037

Hwang, E.; Ko, Y. S.; Jeon, J. 2008. Effect of polymer cement modifiers on mechanical and physical properties of polymermodified mortar using recycled artificial marble waste fine aggregate, Journal of Industrial and Engineering Chemistry 14: 265-271. http://dx.doi.org/10.1016/j.jiec.2008.02.009

Karasahin, M.; Terzi, S. 2007. Evaluation of marble waste dust in the mixture of asphaltic concrete, Construction and Building Materials 21: 616-620.

http://dx.doi.org/10.1016/j.conbuildmat.2005.12.001
Liguori, V.; Rizzo, G.; Traverso, M. 2008. Marble quarrying: an energy and waste intensive activity in the production of building materials, Environmental Economics and Investment Assessment II, WIT Transactions on Ecology and the Environment 108: 197-207. http://dx.doi.org/10.2495/EEIA080201

Malaiskiene, J.; Maciulaitis, R. J.; Mikalauskaite, R. 2014. Possibilities to recycle auto glass waste in building ceramics, Journal of Environmental Engineering and Landscape Management 22(1): 21-29. http://dx.doi.org/10.3846/16486897.2013.867863

Marciukaitis, G.; Jurkenas, G. 2013. Possibilities of using sulphur and plant origin waste for light-weight and thermal insulation construction composites, Journal of Environmental Engineering and Landscape Management 21(2): 106-113. http://dx.doi.org/10.3846/16486897.2013.767805

Marzouk, M.; Abdelhamid, M.; Elsheikh, M. 2013. Selecting sustainable building materials using system dynamics and ant colony optimization, Journal of Environmental Engineering and Landscape Management 21(4): 237-247. http://dx.doi.org/10.3846/16486897.2013.788506

Montero, M. A.; Jordan, M. M.; Almendro-Candel, M. B.; Sanfeliu, T.; Hernandez-Crespo, M. S. 2009. The use of a calcium carbonate residue from the stone industry in manufacturing of ceramic tile bodies, Applied Clay Science 43: 186-189. http://dx.doi.org/10.1016/j.clay.2008.08.003

Okagbue, C. O.; Onyeobi, T. U. S. 1999. Potential of marble dust to stabilise red tropical soils for road construction, Engineering Geology 53: 371-380. http://dx.doi.org/10.1016/S0013-7952(99)00036-8

Saboya Jr., F.; Xavier, G. C.; Alexandre, J. 2007. The use of the powder marble by-product to enhance the properties of brick ceramic, Construction and Building Materials 21: 1950-1960. http://dx.doi.org/10.1016/j.conbuildmat.2006.05.029

Schellmann, W. 1986. A new definition of laterite, Geological survey of India Memoir 120: 1-7.

Segadaes, A. M.; Carvalho, M. A.; Acchar, W. 2005. Using marble and granite rejects to enhance the processing of clay products, Applied Clay Science 30: 42-52. http://dx.doi.org/10.1016/j.clay.2005.03.004

Sivrikaya, O.; Kiyildi, K. R.; Karaca, Z. 2014. Recycling waste from natural stone processing plants to stabilise clayey soil, Environmental Earth Sciences 71: 4397-4407. http://dx.doi.org/10.1007/s12665-013-2833-x

Topcu, I. B.; Bilir, T.; Uygunoglu, T. 2009. Effect of waste marble dust content as filler on properties of self-compacting concrete, Construction and Building Materials 23: 1947-1953. http://dx.doi.org/10.1016/j.conbuildmat.2008.09.007

TRL 1993. Overseas Road Note 31: a guide to the structural design of bitumen-surfaced roads in tropical and sub-tropical countries. Transport Research Laboratory (TRL), Berkshire.

Isaac I. AKINWUMI. Lecturer of Civil Engineering at the School of Applied Engineering, College of Engineering, Covenant University, Ota, Ogun State, Nigeria and doctoral researcher in Civil Engineering at Covenant University. Publications: author/co-author of $\sim 15$ scientific papers. Research interests: soil stabilization/improvement, remediation of contaminated soils, removal of heavy metals from wastewater and soil, waste management, civil engineering materials, sustainability, indigenous construction technologies, and engineering education.

Colin A. BOOTH. Dr, Associate Professor of Sustainability, is Associate Head of Research and Scholarship in the Faculty of Environment and Technology at the University of the West of England, Bristol, UK. Publications: author/co-author of $\sim 130$ scientific papers and chapters. Research interests: sustainability, environmental management, climate change mitigation and adaptation strategies, water resources management, and built environment studies. 